\title{
OVERVIEW OF ENERGY GENERATION AT JEBBA HYDROPOWER STATION (2009-2016)
}

\author{
A. O. Odesola ${ }^{1, *}$ and T. O. Ale ${ }^{2}$ \\ 1, 2, Department of Electrical AND EleCtronics Engineering, Federal University OF TeChNology, \\ P.M.B 704 AKURE, ONDO STATE, NIGERIA \\ E-mail addresses: ${ }^{1}$ demoluin@yahoo.co.uk, ${ }^{2}$ toale@futa.edu.ng
}

\begin{abstract}
This research was carried out to ascertain the relationship between effective reservoir management and hydropower station performance selecting the Jebba Hydroelectric Power Station as a case study. In order to achieve this, the daily inflow and outflow data, as well as the generated energy were collected for the reviewed period (2009 - 2016). The hydrological data indicated that during period under study, the reservoir is recovering at a very low rate. A further analysis was carried out by comparing the conversion efficiency of the energy in flowing water and actual energy generated. Thus the product of the head (metres) and the outflow was plotted against the actual energy generated. The results satisfied a linear relationship having a correlation coefficient of 0.7059 which reinforces the knowledge of the effects of hydropower reservoir management on energy generation.
\end{abstract}

Keywords. Conversion Efficiency, Hydroelectric Power, Inflow, Outflow, Power Station, Reservoir.

\section{INTRODUCTION}

Electrical energy is the most popular form of energy due to its higher efficiency, better controllability, easier bulk power, long distance transportation of power using overhead transmission and underground cables, user friendly, etc. Electricity came to Nigeria in 1896, 15 years after it got to England [1]. Despite its long history in Nigeria, electricity generation is still at its low ebb with power outages being the order of the day. The demand for electricity in the country far outstrips the supply [2].

At present, the three hydro in the country contributes $24 \%$ of the national energy generated, while Jebba hydropower station contributes $39 \%$ of the hydroelectric energy production [3], this is equivalent to $9.36 \%$ of the total energy generated both by hydro and other sources between 2009 and 2016.

Many scholars have carried out studies on reservoir inflow and outflow related issues on hydropower stations, all aimed at proffering solutions to meet the challenging increasing demand in electricity, some of these works are discussed below:
The study in [4] examined the interaction that exist within some reservoir elements such as minimum inflow, storage balance, lake evaporation, average outflow, peak inflow, peak outflow, reservoir level, average inflow, minimum outflow and discharge. It was identified that few elements are most relevant to electricity generation and their level of relevance varies from months to month. However, during low flows the reservoir elements have negligible roles in power generation. Also, in the flood seasons, the output terms are dominant indam operations in order to prevent dam failure and wastage of energy. The study also revealed that a causal relationship exists between hydroelectricity and reservoir elements.

The work in [5] carried out assessment of climate variability on Kainji hydropower reservoir, Niger State, Nigeria, using reservoir inflow data from (1970-2003) from Kainji hydropower station. It was found out that there is slight decrease in reservoir inflow, which may lead to shortage of water for hydropower generation in future.

Analysis of water resources potential and useful life of the Shiroro hydropower reservoir was carried out

* Corresponding author, tel: $\mathbf{+ 2 3 4 - 8 0 3 - 2 2 8 - 0 9 8 1}$ 
by [6] with the view to assessing its current state, operations and management. Suggestions were given as to the other possible ways to reduce siltation and enhance reservoir performance.

The research in [7] investigated the effect of reservoir inflow pattern on hydroelectric power generation in Kainji dam, Niger state, Nigeria. Investigation was conducted using data on reservoir inflow and the amount of power generated for the period of thirty years (1985 - 2014) from Kainji hydropower station. The research indicated that reservoir inflow has a strong relationship on the amount of power generated with a correlation coefficient of 0.92 .

In this work, the effects of hydropower water reservoir management on electric power generation at Jebba hydroelectric power station in Nigeria was studied.

\section{STUDY AREA}

Niger River is the third longest in Africa, after Nile and the Congo/Zaire Rivers, $4100 \mathrm{~km}$ long and it transverses two humid catchments separated by a wide expanse of semi - arid environment ([8],[9]). It has a total length of about $4200 \mathrm{~km}$ with a theoretical area of about 2 million sq $\mathrm{km}$. This area has reduced to an active catchment area of just about 1.5 million sq $\mathrm{km}$ thus excluding Algeria which is among the 10 countries covered by the Niger River basin. Other countries are Benin, Burkina Faso, Cameroon, Chad, guinea, Ivory Coast, Mali, Niger, and Nigeria. The study area, Jebba hydropower reservoir, is located 64 miles from the Kainji dam [10]. The flow of river Niger downstream of Jebba dam is governed by the operations of the Kanji and Jebba hydroelectric schemes and runoff from the catchments [11]. Jebba reservoir depends solely on Kainji discharge during the black flood (Dec to Mar). During white flood (rainy season) some rivers downstream of Kainji discharge in Jebba reservoir in addition to Kainji discharge. Effective water management policy by the station allow the operation of Jebba unit all year round.

\section{METHODOLOGY}

Hydrological data and energy generated from 20092016 was collated from both National Control Centre, Osogbo (NCC) and Jebba Hydroelectric Power Station.

Data relating to energy production as well as hydrological data in Jebba Hydroelectric Power

Nigerian Journal of Technology,
Station (JHPS) was extracted and collated for the period between2009 and 2016. These data include; Hydrological data (Inflow, Outflow, Head Water Elevation, Tail Water Elevation), daily energy produced, and daily fault occurrence at JHPS. The collated data was studied using Time series analysis and Correlation in Microsoft Excel Software Environment.

The effect of water inflow and the reservoir condition on power generation for the studied period were related using equation (1). The initial value of the reservoir health variable is arbitrarily set to zero for easy analysis.

$$
R_{n+1}=R_{n}+Q_{i, n}-Q_{o, n}
$$

where $R_{n+1}$ is the net cummulative inflow in $\mathrm{m}^{3} / \mathrm{s}$

$R_{n}$ is the reservoir health variable in $\mathrm{m}^{3} / \mathrm{s}$

$Q_{i, n}$ is the inflow at interval $n$ in $\mathrm{m}^{3} / \mathrm{s}$

$Q_{o, n}$ is the outflow at interval $n$ in $\mathrm{m}^{3} / \mathrm{s}$

$n$ is the index for the year

A spread sheet procedure in Microsoft Excel software environment was developed for easy evaluation of the hydropower conversion efficiency using equation (2). This was compared with the actual power generated for efficiency analysis.

$$
P=\eta \rho g Q H
$$

where, $P$ is power in watts.

$\rho$ is the density of water $\left(\mathrm{kg} / \mathrm{m}^{3}\right)$

$g$ is the acceleration due to gravity $\left(9.81 \mathrm{~m} / \mathrm{s}^{2}\right)$

$H$ is the effective head of water in $(m)$

$Q$ is the rate of flow of water in $\left(\mathrm{m}^{3} / \mathrm{s}\right)$.

$\eta$ is the turbine efficiency (\%)

\section{RESULTS AND DISCUSSION}

Figure 1 shows the plot of the time series of JHPS daily inflow from January 2009 till December 2016. The plot indicates a cyclical pattern although not too strong, indicating two peaks occurring each year. Seasonal flows are apparent from the time series with twin peaks occurring annually corresponding to the black flood and the white floods respectively. The daily inflow data was later averaged into monthly scales as shown in Figure 2.

Figure 3 presents both the inflow and the outflow observed over the period of 2009 and 2016. It shows that the inflow and outflow seems to be consistent. The average value of the head is around the upper limit set by the designer -27 metres. The difference between the inflow and outflow were evaluated and the cumulative value was plotted as shown in Figure 4. The figure shows that the reservoir is recovering 
at a very small rate, but if the reservoir is properly managed, there will be improvement in the recovery rate.

The time series plot of the monthly power generated at JHPS is depicted in Figure 5. It shows that the generated power has peaks which are not strictly in step with the inflow as a result of scheduled and forced outages of the plants in the station. The aggregate efficiency of conversion is $83.79 \%$ which is less than the $90 \%$ theoretical value for propeller type turbines was obtained.

A further analysis was carried out by comparing the conversion efficiency of the energy in flowing water and actual energy generated. Thus the product of the head (metres) and the outflow was plotted against the actual energy generated and this is shown in Figure 6.

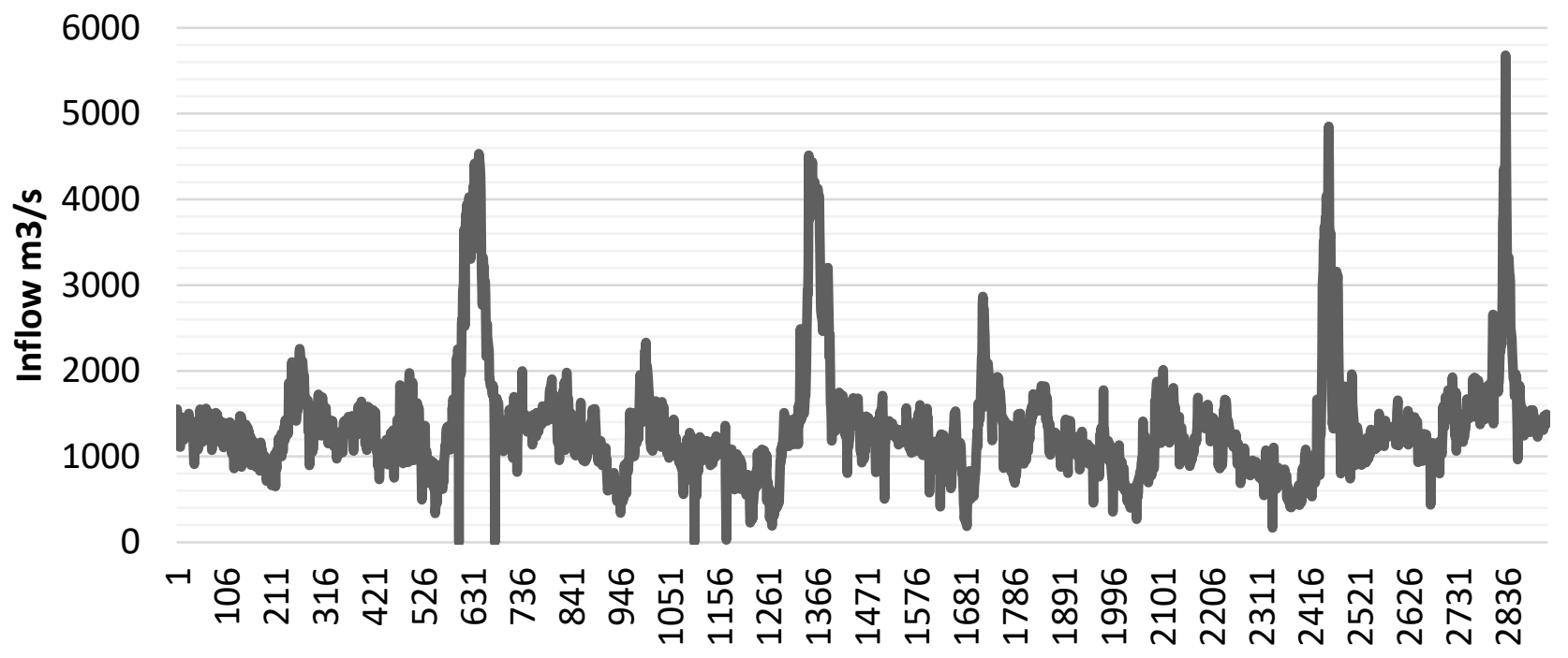

Figure 1: Time Series Of Jebba Inflow 2009-2016

days

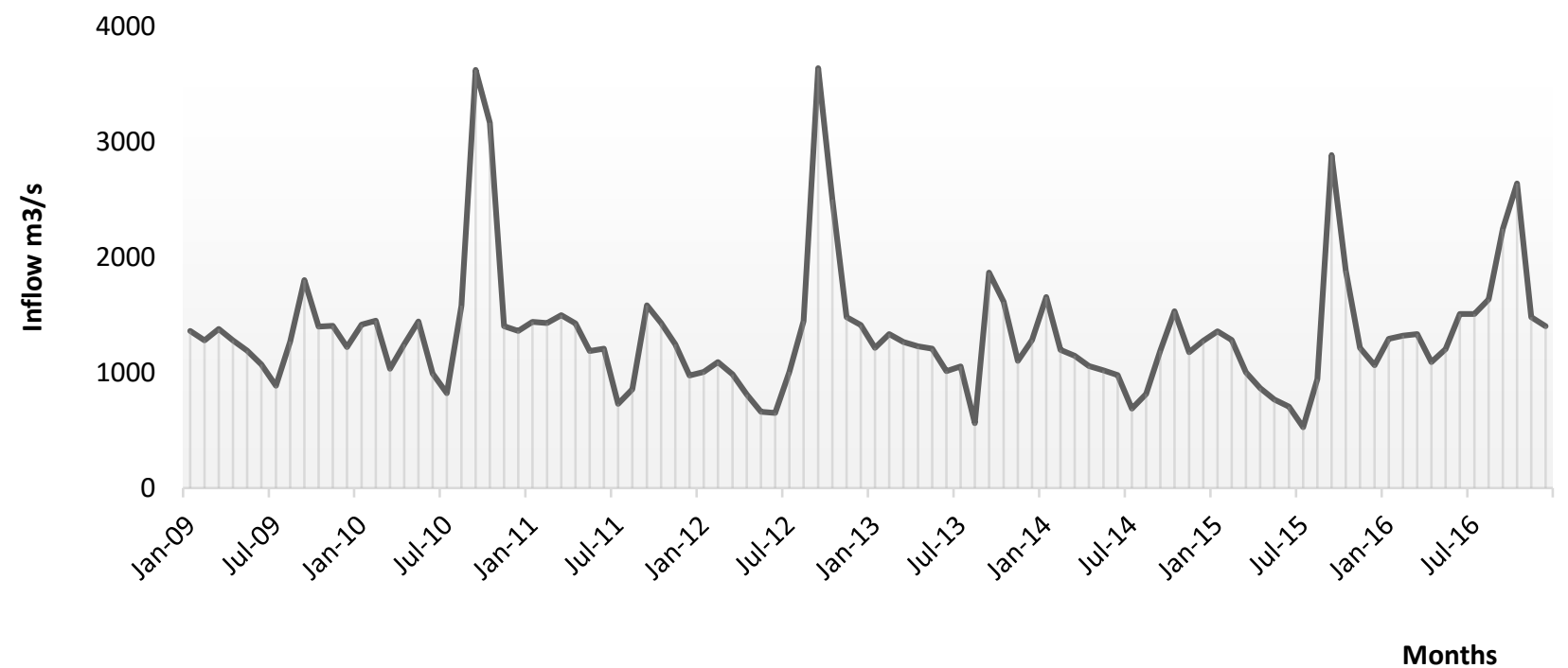

Figure 2: Time Series of Jebba monthly inflow 2009-2016 


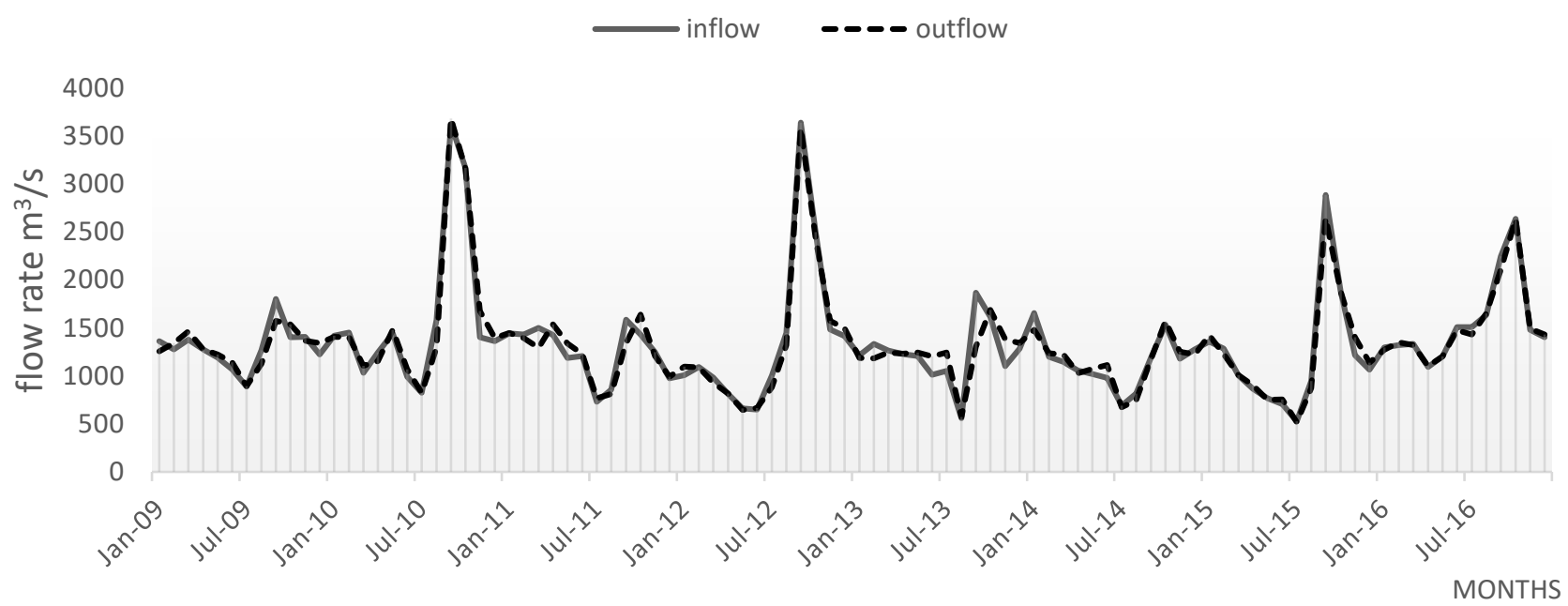

Figure 3: Time Series of Jebba monthly inflow and outflow 2009-2016

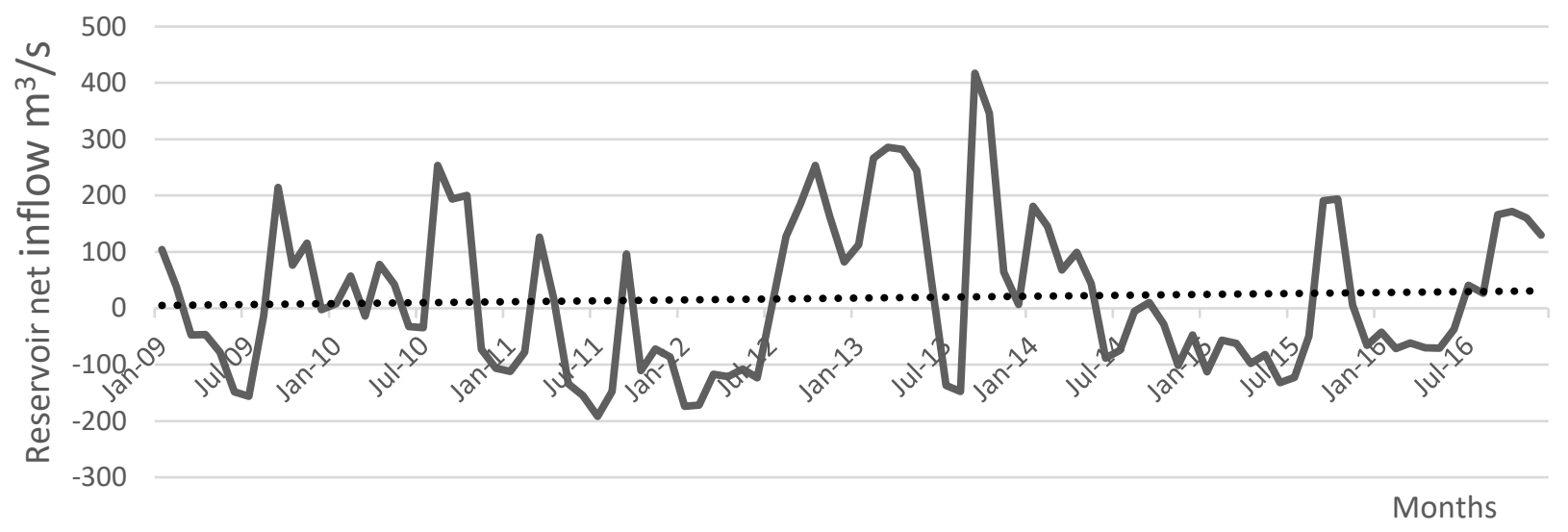

Figure 4: Cumulative reservoir inflow jebba 2009-2016

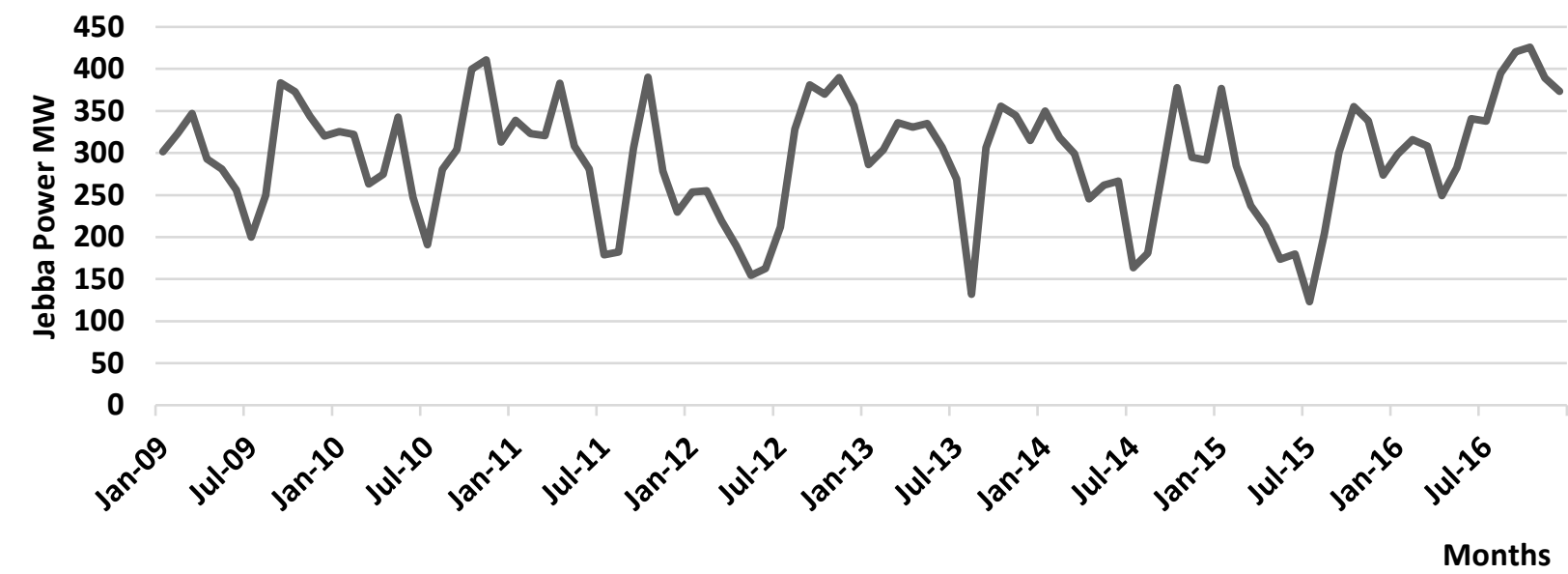

Figure 5: Jebba Power Generated Trend (MW) 


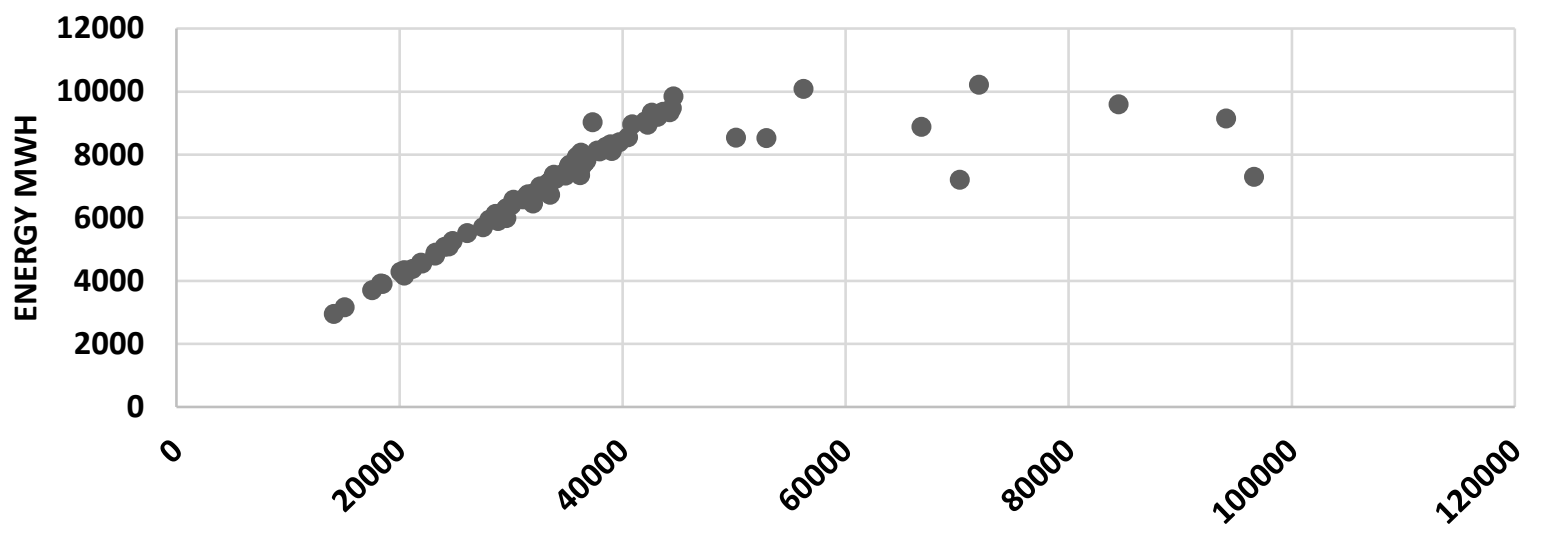

Figure 6: Energy vs Head*outflow

HEAD*OUTFLOW

The resulting scatter diagram reveals a cluster of points almost satisfying a linear relationship but some strong component deviate from this cluster. This deviation was well noticed under high outflow condition, which shows that a significant part of the outflow was spilled (wasted) rather than used to operate the turbines for power generation.

\section{CONCLUSION}

This work done has used the information to study power generation at the dam. The hydrological data indicated that during period under study, the reservoir is recovering at a very low rate.

A further analysis was carried out by comparing the conversion efficiency of the energy in flowing water and actual energy generated. Thus the product of the head (metres) and the outflow was plotted against the actual energy generated.

The results satisfied a linear relationship which reinforces the knowledge of the effects of hydropower reservoir management on energy generation.

\section{RECOMMENDATIONS}

Having carried out this research, the following were recommended:

1. The reservoir should be properly managed to avoid water wastage especially during the condition of high water inflow.

2. Prompt response to faults should be ensured.

3. Spares parts should be made readily available so as to reduce the downtime to the barest minimum.

\section{REFERENCES}

[1] Ale, T. O. and Odesola, A. O. "Effects of Distance on Transmission (Akure 33kV line a case study)", International Journal of Research Findings in Engineering, Science and Technology, Vol. 1, No.1., 2013, pp 27-32.

[2] Zungeru, A. M.; Araoye, A. B.; Garegy, B. B.; Garba, A. J. and Tola, O. J. "Reliability Evaluation of Kainji Hydro-Electric Power Station in Nigeria", Journal of Energy Technologies and Policy, Vol.2, No.2, 2012, pp 15-31.

[3] Annual Technical Report - ATR "Grid System Operations", Annual Technical Report Issued by National Control Centre Osogbo. 2015, pp 1-86.

[4] Ifabiyi, I. P. "Relationship between Power Generation and Reservoir Elements in the Jebba Hydroelectric Reservoir, Nigeria", Global Journal of Science Frontier Research, Vol. 11, Issue 8, 2011, pp. 1-11.

[5] Salami, A. W. and Sule, B. F. "Optimal Water Management Modeling for Hydropower System on River Niger in Nigeria", International Journal of Engineering, Annals of Faculty of Engineering Hunedoara, Tome X, 2012, pp. 185-192.

[6] Adie, D. B.; Ismail, A.; Muhammad, M. M. and Aliyu, U. B. "Analysis of the Water Resources Potential and Useful life of the Shiroro Dam, Nigeria" Nigerian Journal of Basic and Applied Science, Vol. 20, No. 4, 2012, pp 341-348.

[7] Adegbehin, A. B, Yusuf Y. O Iguisi E. O and Zubairu, I. "Reservoir inflow pattern and its effects on hydroelectric power generation at the Kainji Dam, Niger State, Nigeria", Proceeding of 
the 3rd international conference on Environmental and Economic Impact on Sustainable Development (EID), Vol. 203, 2016 pp 233-244.

[8] Alayande, A. W. and Bamigboye, O. A. "Tail water Recycling for Hydropower Generation, Niger River", 29th WEDC International Conference Abuja Nigeria, 2003, pp 175-177.

[9] Ale, T. O., Alowolodu, K. E., Babatola, J. O. and Olufeagba, B. J. "Inflow Forecasting for Kainji Dam Using Time Series Model", International Journal of Mathematical Archive (IJMA), Vol. 2, No. 12, 2011, pp 2844-2851.
[10] Jimoh, O. D. "Optimized Operation of Kainji Reservoir", Assumption University Journal of Technology (AUJ.T.), Vol. 12, No. 3, 2008, pp 34-42.

[11] Sule, B. F., Salami, A. W. and Okeola, O. G. "Operational Impact of Hydropower Generation and Highlights on Preventive Measures in Lowland Area of River Niger, Nigeria", International Electronic Engineering Mathematical Society IEEMS, Vol. 7. No 1, 2009, pp. $109-126$. 